\title{
Persistency Measurement in HF $\times$ Sahiwal Cattle
}

\section{Nisha Sharma ${ }^{1 *}$, Raman Narang ${ }^{2}$, Poonam Ratwan $^{1}$, Neeraj Kashyap ${ }^{2}$, Soni Kumari ${ }^{3}$ and Simarjeet Kaur ${ }^{2}$}

\author{
${ }^{1}$ ICAR-National Dairy Research Institute, Karnal - 132001 (Haryana) India \\ ${ }^{2}$ Guru Angad Dev Veterinary and Animal Sciences University, Ludhiana-141004 (Punjab) India \\ ${ }^{3}$ Indian Veterinary Research Institute, Izatnagar-243122 (Uttar Pradesh) India
}

*Corresponding author

A B S T R A C T

\begin{tabular}{|l|}
\hline K e y w o r d s \\
HF $\times$ Sahiwal \\
cattle, Daily milk \\
yield, Persistency.
\end{tabular}

\section{Introduction}

Crossbred cattle hold a key position in the growth of dairy sector in India as crossbred cattle though merely $13.26 \%$ of total bovine population of India, yet they contribute 24.46 $\%$ of total milk yield by bovines. In the state of Punjab, where dairy farming is more developed, wide acceptance of crossbred cattle is evident from the fact that $85.06 \%$ of total cattle in Punjab are crossbreds (Basic Animal Husbandry Statistics, 2015). In India, there are 41 registered breeds of cattle (NBAGR 2017). In spite of large genetic resources, productivity remains low. Milk productivity can be increased by crossing low milk producing indigenous cattle with high yielding exotic cattle. Main aim of animal breeder is to enhance genetic improvement in important economic traits. The success of dairy industry is much dependent on level of production and reproductive traits of animals. 
Main income for most dairy farmers is based on milk, fat and protein yields of their cattle. As a matter of fact, if profits are a function of returns minus costs, reduction of costs must be considered to improve profits when increases in returns are limited. A way to reduce costs is to distribute same total yield more equally over the whole lactation. This distribution of lactation yield is known under the name of persistency of lactation yields, often simply called persistency.

In cattle, economy of milk production depends mainly on milk produced in different lactations. According to Narain et al., (1981) and Ramachandraiah et al., (1990) milk yield in a lactation depends mainly on persistency, peak yield and lactation length. More persistent animal produces relatively higher milk and therefore, have longer productive life. Persistency of milk yield can be defined in many ways. According to Wood (1967), persistency is "the extent to which peak yield is maintained". Jamrozik et al., (1998) defined persistency of lactation as ability of animal to continue producing milk at a high level after reaching peak of her lactation.

In dairy cattle, milk yield increases rapidly from calving to peak period of yield in a few weeks, thereafter it gradually decreases until milking is no longer practical (Leon-Velard et al., 1995). Persistency of milk is always considered to have more advantages for selection. Solkner and Fuchs (1987) found that more persistent cows have lesser feed intake cost and contribute to more economic returns from animal by increasing the lactation milk yield, resulting in increased profitability. Low individual persistency of milk yield is governed by certain genetic and non-genetic factors. More persistent animals have been reported to have higher lactation milk yields as reported by Ludwick and Peterson (1943), Mahadeven (1951) and Saxena and Kumar (1960).

\section{Materials and Methods}

A total of 577 milk yield records (305days/less) of first lactation from 1991 to 2015 (25 years) were collected for crossbred ( $\mathrm{HF} \times$ Sahiwal) cows sired by 84 bulls maintained at Directorate Livestock Farm, GADVASU, Ludhiana. Normal lactation was considered as the period of milk production by a cow for at least 200 days.

Data were divided into five periods of five year duration each viz., 1991-1995, 19962000, 2001-2005, 2006-2010 and 2011-2015. Each year was divided into four seasons viz. winter, spring, summer, rainy of three month duration each. Animal were grouped on the basis of exotic inheritance into four groups viz., $<75 \%,=75 \%,>75 \leq 87.5 \%$ and $>87.5 \%$.

Level of production was divided into three classes viz., low producers (< 2861.45), medium producers (2861.45 - 4033.88) and high producers (>4033.88) based on 305 days milk yield. Different measures of persistency were calculated using ratios of milk production in different section of lactation as follows:

\section{Khmel'Nit skii method}

Persistency $=\frac{\text { Peakyield }}{\text { a05-daymilkyield }} X 100$

Average weekly milk yield data for first lactation was utilized to estimate the persistency by the method of Sturtevent (1887) as modified by Pradhan and Dave (1973)

((8th week's yield / 7th week's yield $) \times 100+$ (9th week's yield / 8th week's yield) $\times 100+$ (42nd week's yield / 41th week's yield) $\times 100$ ) / N-1

$\mathrm{N}=$ Total no. of weeks included (42 weeks) 


\section{Statistical model}

Data were analyzed by using Least Squares Analysis as described by Harvey (1990) to study the effects of various genetic and nongenetic factors on persistency calculated by different methods using following model:

$\mathrm{Y}_{\mathrm{ijklmn}}=\mu+\mathrm{B}_{\mathrm{i}}+\mathrm{S}_{\mathrm{j}}+\mathrm{P}_{\mathrm{k}}+\mathrm{L}_{\mathrm{l}}+\mathrm{GG}_{\mathrm{m}}+\mathrm{e}_{\mathrm{ijklmn}}$

Where, $Y_{\mathrm{ijklmn}}=$ Persistency index of $\mathrm{n}^{\text {th }}$ cow sired by $\mathrm{i}^{\text {th }}$ bull, calved in $\mathrm{j}^{\text {th }}$ season, $\mathrm{k}^{\text {th }}$ period, having $1^{\text {th }}$ level of production and $\mathrm{m}^{\text {th }}$ level of genetic group (level of exotic inheritance) $; \mu$ is overall population mean; $B_{i}$ is random effect of $i^{\text {th }}$ sire; $S_{j}$ is fixed effect of $j^{\text {th }}$ season; $P_{k}$ is fixed effect of $k^{\text {th }}$ period; $L_{1}$ is fixed effect of $1^{\text {th }}$ level of production; $\mathrm{GG}_{\mathrm{m}}$ is fixed effect of $\mathrm{m}^{\text {th }}$ level of genetic group (level of exotic inheritance) and $e_{i j k l m n}$ is random error assumed to be $\operatorname{NID}\left(0, \sigma_{\mathrm{e}}{ }^{2}\right)$

\section{Results and Discussion}

The overall least squares means of persistency indices calculated by Khmel'Nit skii (1974) and Strutevent (1987) method were found to be $0.56 \pm 0.11$ and $84.2 \pm 1.45$, respectively (Table 2). Effect of genetic group was found to be non-significant on persistency calculated by Khmel'Nit skii (1974) and Strutevent (1887) method as shown in (Table 1).

Effect of period of calving was found to be significant for P1 method. Persistency of milk yield was non-significantly $(\mathrm{P}<0.05)$ affected by level of production and season by $\mathrm{P} 1$ method. The persistency of milk production was measured in Holstein Friesian cattle up to $42^{\text {nd }}$ week of lactation and overall persistency (\%) for weekly milk production in first lactation was observed to be $84.22 \%$. Patel et al., (2015) reported $84.45 \%$ persistency of milk yield by P2 method and this was in accordance with our results. Values obtained by Zakariyya et al., (1995) and Ahmad et al.,
(2003) for persistency of milk yield by Ludwick and Peterson (1943) method were $91.31 \pm 0.55 \mathrm{~kg}$ and $90.5 \pm 0.01 \mathrm{~kg}$, respectively. Persistency of milk yield was significantly $(\mathrm{P}<0.05)$ affected by season of calving and level of production by Strutevent method. Significant effect of season of calving was observed by Pradhan and Dave (1973), Yadav et al., (1992), Rao and Sundaresan (1982), Prasad et al., (1999) and Kumar and Singh (2006) by Ludwick and Peterson method. On contrary, non-significant effect of season of calving was reported by Koley et al., (1979) in Jersey $\times$ Hariana, Roy and Katpatal (1987) in Jersey cattle and Patond et al., (2014) in Jersey cattle.

Effect of period of calving was found to be significant for P1 method in present study. Significant effect of period of calving on persistency was reported by Shah et al., (1983) in HF crossbred and Patond et al., (2014) in Jersey cattle by Ludwick and Peterson method. Similar significant effect of period of calving on persistency has also been reported by Wondifraw et al., (2013) and Garudkar et al., (2015) by Mahadevan method. However, non-significant effect of period of calving on persistency has been reported by Kumar and Singh (2006) in Karan Fries cattle and Patond et al., (2014) in Jersey cattle by Mahadevan method.

Genetic group had non - significant effect on both persistency indices because most of animals in the herd had exotic inheritance of $75 \%$ or more than $75 \%$ as shown in Table 2. Significant effect of period of calving could be due to change in climate, feeding, management and genetic constituent of the herd over the years (periods). Significant effect of period of calving could be due to continuous availability of green fodder and conductive weather conditions for longer duration during pre-peak and post peak periods. 
Table.1 Analysis of variance for factors affecting different measures of persistency indices

\begin{tabular}{|c|c|c|c|}
\hline \multirow{2}{*}{$\begin{array}{c}\text { Source of } \\
\text { variation }\end{array}$} & \multirow{2}{*}{$\begin{array}{c}\text { Degree of } \\
\text { freedom }\end{array}$} & \multicolumn{2}{|c|}{ Mean sum of squares } \\
\cline { 3 - 4 } & 3 & $\mathrm{P} 1$ & $\mathrm{P} 2$ \\
\hline Genetic group & 3 & 0.021 & 0.479 \\
\hline Season & 4 & 0.007 & $37.54^{*}$ \\
\hline Period & 2 & $0.11^{* *}$ & 2.54 \\
\hline Level of production & 2 & 0.029 & $7.20^{* *}$ \\
\hline
\end{tabular}

Values carrying * and ** are significant at 0.05 and 0.01 levels of probability, respectively

Table.2 Least-squares means along with standard errors of different measures of persistency indices in crossbred cattle

\begin{tabular}{|c|c|c|c|}
\hline Factor & No. of observations & $\mathbf{P}_{\mathbf{1}}$ & $\mathbf{P}_{\mathbf{2}}$ \\
\hline Overall mean & 577 & $0.56 \pm 0.11$ & $84.2 \pm 1.45$ \\
\hline Genetic group & \multicolumn{3}{|l|}{} \\
\hline$<75 \%$ & 37 & $0.52 \pm 0.017$ & $84.17 \pm 0.21$ \\
\hline$=75 \%$ & 386 & $0.56 \pm 0.006$ & $84.13 \pm 0.08$ \\
\hline$>75 \leq 87.5 \%$ & 116 & $0.55 \pm 0.011$ & $84.24 \pm 0.13$ \\
\hline$>87.5 \%$ & 28 & $0.56 \pm 0.02$ & $84.36 \pm 0.28$ \\
\hline Level of Production & 164 & $0.56 \pm 0.012$ & $83.94 \pm 0.15$ \\
\hline$<2861.45$ & 199 & $0.53 \pm 0.010$ & $84.45 \pm 0.12$ \\
\hline $2861.45-4033.88$ & 214 & $0.54 \pm 0.010$ & $84.27 \pm 0.12$ \\
\hline$>4033.88$ & 139 & $0.55 \pm 0.010$ & $83.68 \pm 0.13$ \\
\hline Season of calving & 174 & $0.54 \pm 0.010$ & $84.70 \pm 0.13$ \\
\hline Winter & 134 & $0.55 \pm 0.011$ & $84.63 \pm 0.14$ \\
\hline Spring & 130 & $0.55 \pm 0.011$ & $83.88 \pm 0.14$ \\
\hline Summer & 137 & $0.58 \pm 0.012$ & $84.05 \pm 0.15$ \\
\hline Autumn & 166 & $0.57 \pm 0.011$ & $84.37 \pm 0.14$ \\
\hline Period of calving & 101 & $0.52 \pm 0.013$ & $84.14 \pm 0.16$ \\
\hline $1991-1995$ & 91 & $0.57 \pm 0.013$ & $84.37 \pm 0.17$ \\
\hline $1996-2000$ & 82 & $0.49 \pm 0.014$ & $84.19 \pm 0.18$ \\
\hline $2001-2005$ & \multicolumn{3}{l}{}
\end{tabular}

However in winter calvers there is sharp decline in milk production during post peak period due to higher temperature of ensuing summer months by Strutevent method.

Thus it appears that it is not merely calving the season of calving but also the supply of nutritive diet through availability of green fodders at different stages of lactation which makes the cow persistent. In conclusion, different non-genetic factors affect persistency of milk yield in first lactation.

So, data should be adjusted for significant non-genetic factors to get accurate estimates of persistency.

Further, for first lactation milk yield good persistency can be obtained in Holstein Friesian $\times$ Sahiwal cattle. 


\section{Acknowledgements}

The authors are thankful to the Vice Chancellor of GADVASU and Head of GADVASU, Ludhiana for providing the necessary facilities. We wish to acknowledge the hard work and sincerity of the staffs of Directorate Livestock Farm.

\section{Conflict of Interest Statement}

The authors declare that they have no conflict of interest.

\section{References}

$19^{\text {th }}$ Livestock census, 2012. All India Report. dahd.nic.in/dahd/WriteReadData/Livest ock.pdf

Ahmad, N., Shah, S.I., Farooq, M., and Gill, R.A. 2003. Lactation Yield, Length and persistency of Lactation in Holstein Cows under the subtropical Environment of North West frontier province (NWFP). Journal of Animal and Veterinary Advances, 2, 548-553.

Basic Animal Husbandry Statistics, 2015. Ministry of Agriculture, Department of Animal husbandry, Dairying and Fisheries.

Garudkar, S.R., Patond, M.N., and Deokar, D.K., 2015. Effect of Non-genetic Factors on Some Productive Traits in Phule Triveni Synthetic Cows. Indian Journal of Veterinary Research, 24, 2326.

Jamrozik, J., Jansen, G., Schaeffer, L.R., and Liu, Z., 1998. Analysis of persistency of lactation calculated from a random regression test-day model. Interbull Bulletin, 17, 64-69.

Khmel'Nit skii, V.V.,1974. Persistency of lactation as a selection trait in Yaroslawl cows. Animal Breeding Abstr 42: 1696 (Abstr).

Koley, N., Chaudhary, G., and Mitra, D.K.,
1979. Persistency of lactation yield in Jersey, Hariana crossbred cows. Indian Journal of Dairy Science, 32, 302-305.

Kumar, A., and Singh, A., 2006. Genetic and environmental factors influencing persistency of milk production in Karan fries cattle. Indian Journal of Animal Science, 40, 45-100.

Leon-Velard, C.U., Mcmillan, I., Gentry, R.D., and Wilton J., 1995. Models for estimating typical lactation curves in dairy cattle. Journal of Animal Breeding and Genetics, 112, 333-340.

Ludwick, T.M., and Petersen, W.E., 1943. A measure of persistency of lactation in dairy cows. Journal of Dairy Science, 26, 439-445.

Mahadevan, P., 1951. The effect of environment and heredity on lactation. II. Persistency of lactation. Journal of Agriculture Science, 41, 89-93.

Narain, P., Kumar, K., and Duita, O.P., 1981. Inheritance of part lactation and estimation of persistency of milk yield in Sahiwal cattle. Indian Journal of Animal Genetics and Breeding 3, 4-10.

NBAGR, 2017. http: //www.nbagr.res.in/ registeredbreed.html

Patel, A.C., 2015. Study on Persistency of milk production in Holstein Friesian cattle on an organized farm. International Journal of Applied and Pure Science and Agriculture, 1, 239483

Patond, M.N., Khutal, B.B., Pachpute, S.T., and Ramod, S.S., 2014. Effect of nongenetic factors on persistency of milk yield in Jersey cattle. Veterinary Science Research Journal, 5, 1-4.

Pradhan, V.D., and Dave, A.D., 1973. A study on the lactation curve and the rate of decline in milk yield in Kankrej cattle. Indian Journal of Animal Science, 43, 914-917.

Prasad, S., Singh, R., and Bisht, G.S., 1999. Measure of persistency and its 
relationship with peak yield and lactation milk yield. Indian Journal of Dairy Science, 52, 308-314.

Ramachandraiah, K.K., Sudharshan, K., and Sreemannarayana, O., 1990. A study on Lactation persistency in relation to certain economic traits in purebred Jersey cows. Indian Journal of Dairy Science, 43, 270-277.

Rao, M.K., and Sundaresan, D., 1982. Factors affecting the shape of lactation curve in Friesian $\mathrm{x}$ Sahiwal crossbred cows. Indian Journal of Dairy Science, 35, $160-166$.

Roy, T.C., and Katpatal, B.G., 1987. Genetic studies on persistency of first lactation yield in Jersey cattle. Livestock Advisor, 12, 17-21.

Saxena, P.N., and Kumar, S., 1960. Persistency of milk yield in Sahiwal cows. Indian Journal of Dairy Science, $13,45-60$.

Solkner, J., and Fuchs, W., 1987. A comparison of different measures of persistency with special respect to variation of test-day yields. Livestock
Production Science, 16: 305-319.

Sturtvant, E.L., 1887. Influence of distance from calving on milk yield, N.Y. (Geneva). Agri. Expt. Sta. Ann. Rept. 5: 26. c.f. Arya, J.S. (1983).

Wondifraw, Z., Thombre, B.M., and Bainwad, D.V., 2013. Effect of nongenetic factors on milk production of Holstein Friesian $\times$ Deoni crossbred cows. International Journal of Livestock Production, 4, 106-111.

Wood, P.D P, 1967. Algebraic model of the lactation curve in cattle. Nature, 164165.

Yadav, A.S., Rathi, S.S., Dahiya, S.P., and Arora, D.N., 1992. Factors affecting some performance traits in Sahiwal cattle. Indian Journal of Dairy Science, 45, 522-526.

Zakariyya, M., Babar, M.E., Yaqoob, M., Lateef, M., Ahmad, T., and Bilal, M.Q., 1995. Environmental factors affecting persistency of lactation and peak milk yield in nili-ravi buffaloes. Pakistan Journal of Agriculture Science, 32, 24925

\section{How to cite this article:}

Nisha Sharma, Raman Narang, Poonam Ratwan, Neeraj Kashyap, Soni Kumari and Simarjeet Kaur. 2017. Persistency Measurement in HF $\times$ Sahiwal Cattle. Int.J.Curr.Microbiol.App.Sci. 6(12): 1849-1854. doi: https://doi.org/10.20546/ijcmas.2017.612.210 